\title{
Do Environmental Performance and Renewable Energy Move Together?
}

\author{
Chun-Ping Chang ${ }^{1 a}$, Quan-Jing Wang ${ }^{2 b}$ \\ ${ }^{1}$ Shih Chien University, Taiwan, ${ }^{2}$ Business School, Zhengzhou University, China \\ Keywords: cointegration, renewable energy, $\mathrm{co} 2$ \\ https://doi.org/10.46557/001c.25731
}

\section{Energy RESEARCH LETTERS}

Vol. 2, Issue 2, 2021

This study aims to examine the cointegration and causal links between carbon dioxide (CO2) emissions and renewable energy by employing panel data covering 41 countries from 1973 to 2017. Our empirical results suggest that CO2 emissions and renewable energy move together in Organisation for Economic Co-operation and Development (OECD) countries, but not in non-OECD countries. There exists a long-run causal flow from renewable energy to $\mathrm{CO} 2$ emissions in OECD countries, and vice versa. However, there is a unidirectional causal flow from $\mathrm{CO} 2$ emissions to renewable energy in non-OECD countries in the long run.

\section{Introduction}

Environmental pollution is a serious problem worldwide that brings about negative externality and challenges, thus eventually harming individual lives and national development. A growing strand of literature investigates the factors of environmental pollution, such as economic development, political regimes, and industrial structure, as well as energy consumption and energy efficiency (Chang \& Hao, 2017; Narayan \& Narayan, 2010; K. Wang et al., 2020). However, few studies examine whether the share of renewable energy to total energy consumption can affect environmental pollution (Chen et al., 2019; Hu et al., 2020), and none focuses on the bidirectional relation between environmental pollution and renewable energy. We try to uncover the long-run bidirectional relation between environmental pollution and renewable energy to fill this research gap in the literature.

Theoretically, environmental performance is causally linked to renewable energy use, because, in comparison with traditional energy sources such as crude oil and coal, the utilization of renewable energy creates few emissions and its generation is environmentally friendly. Thus, renewable energy would affect environmental performance (Yang et al., 2021). From another perspective, carbon dioxide (CO2) emissions can affect energy consumption and thus induce shocks to clean energy investment, which would affect the share of renewable energy to total energy consumption (Chen et al., 2021). Empirically, for instance, Y. Wang and Zhi (2016) noted that it is critical to protect the environment by sustainably utilizing renewable energy. He et al. (2019) pointed out that investment in renewable energy would benefit environmental performance. Similarly, Dubey et al. (2015) proposed that better environmental performance requires the participants to carry out their organizational processes, production activities, and energy utilization in a manner that meets legal environmental protection requirements (Darnall et al., 2008).

The novelties of our study are as follows. We empirically test the relation between $\mathrm{CO} 2$ emissions and renewable energy by using data for 41 countries from 1973 to 2017 and Pedroni's (2004) cointegration test, which has been ignored by previous literature (Chen et al., 2021; Yang et al., 2021). Our empirical results show that $\mathrm{CO} 2$ emissions and renewable energy move together in Organisation for Economic Co-operation and Development (OECD) countries, but not in non-OECD countries. In addition, we examine the shortand long-run causal links between $\mathrm{CO} 2$ emissions and renewable energy with a panel vector error correction model (VECM), as well as the differences of these bidirectional causal links between OECD and non-OECD countries, filling the gap in the literature (He et al., 2019). Our results support a long-run causal flow from renewable energy to CO2 emissions in OECD countries, and vice versa. However, there is unidirectional causal flow from $\mathrm{CO} 2$ emissions to renewable energy in non-OECD countries in the long run.

\section{A. Variables and Data \\ II. Data and Methodology}

This paper utilizes panel data for 41 countries from 1973 to 2017 to test the relation between $\mathrm{CO} 2$ emission and

\footnotetext{
a cpchang@g2.usc.edu.tw

b Corresponding author: Quan-Jing Wang, W_quanjing@163.com
} 
Table 1. Summary of descriptive statistics

\begin{tabular}{lcccccc}
\hline Variable & $\mathrm{N}$ & Mean & SD & Min & Median \\
\hline Renew & 1845 & 0.129 & 0.330 & 0.000 & 0.000 \\
CO2 & 1845 & 4.536 & 1.719 & 0.511 & 4.287 & 9.192 \\
\hline
\end{tabular}

This table shows the descriptive statistics of the variables, which are observations (N), mean (Mean), standard deviation (SD), median (Median), minimum (Min), and maximum (Max).

energy structure. In line with Y. Wang et al. (2021), we use $\mathrm{CO} 2$ emissions ( $\mathrm{CO} 2$ ) to measure environmental quality. The CO2 data of some countries are sourced from the World Development Indicators (2020), in units of a thousand tons. ${ }^{1}$ Renewable energy, denoted by Renew, is captured by the share of renewable energy, such as solar, wind, and tidal energy, in the total consumption of energy,. Data for Renew are derived from the International Energy Agency (2020). ${ }^{2}$ All data are transformed into natural logarithmic form.

Table 1 presents the basic statistics, which show that the mean of Renew is 0.129 with a standard deviation of 0.330 , suggesting that Renew does not fluctuate much among these 41 countries. The mean, standard deviation, minimum, and maximum for $\mathrm{CO} 2$ are 4.536, 1.719, 0.511, and 9.192, respectively, implying that $\mathrm{CO} 2$ emissions vary among our sample countries.

\section{B. Methods}

We employ panel cointegration test proposed by Pedroni (2004) to uncover the relation between CO2 and Renew:

$$
\begin{aligned}
& y_{i t}=\phi_{i}+\gamma_{i} t+x_{i t}^{\prime} \beta_{i}+\mu_{i t}, \\
& \quad i=1, \ldots, N, t=1, \ldots, T,
\end{aligned}
$$

where $y_{i t}$ represents $C O 2_{i t}, x_{i t}$ represents Renew ${ }_{i t} ; \phi_{i}$ and $\gamma_{i}$ are individual fixed effects and deterministic trends, respectively, both allowing for differences among countries; and $\mu_{i t}$ is a residual.

\section{Results}

Once the stationary tests suggest that these two variables follow an I(1) process, ${ }^{3}$ we further carry out panel cointegration to examine whether long-run bidirectional relations exist between $\mathrm{CO} 2$ and Renew. The results of the Pedroni (2004) cointegration test are listed in Table 2. For the full sample, we find that the statistics of Panel variance, Panel PP, and Panel ADF are significant at least at the 10\% level, confirming a cointegration relation between $\mathrm{CO} 2$ and Renew. The results for the two subsamples support $\mathrm{CO} 2$ and Renew comoving among OECD countries, but no cointegration between $\mathrm{CO} 2$ and Renew among non-OECD countries. Our finding is in line with that of He et al. (2019), who pro- posed that renewable energy benefits environmental performance.

Under the premise that $\mathrm{CO} 2$ and Renew comove, we further investigate the bidirectional causal links between $\mathrm{CO} 2$ and Renew in the short or long term via a panel VECM. Table 3 provides the results of the panel VECM. First, if the dependent variable is $\triangle \mathrm{CO} 2$, the statistic of $\triangle$ Renew is 0.58 and not significant at the $10 \%$ level, offering evidence of no causal link from Renew to $\mathrm{CO} 2$ in the short term. The $\lambda$ statistic is 4.72 , significant at the $5 \%$ level, indicating a shock from Renew to $\mathrm{CO} 2$ in the long run. A joint test of the error correction model and Renew also supports the same idea. These findings support those of Y. Wang and Zhi (2016), who suggested that renewable energy benefits environmental performance. Similarly, based on the results where $\Delta R e$ new is a dependent variable, we see that $\mathrm{CO} 2$ cannot affect Renew in the short term, but a significant shock exists from CO2 to Renew in the long term. This finding is similar to that of Chen et al. (2021), who argued that climate change would lead to clean energy investment.

For OECD countries, we find that renewable energy exerts a causal impact on $\mathrm{CO} 2$ emissions in both the short and long run, while the causal link from $\mathrm{CO} 2$ emissions to renewable energy is only established in the long run. For non-OECD countries, we find that renewable energy does not change $\mathrm{CO} 2$ emissions in the short or long run, while CO2 emissions only exert a causal link on renewable energy in the long run.

\section{Conclusions}

This research investigates the relation between $\mathrm{CO} 2$ emissions (CO2) and the utilization of renewable energy (Renew) by employing data for 41 countries from 1973 to 2017 and estimations such as the Pedroni (2004) cointegration test, fully modified ordinary least squares, and a panel VECM. Pedroni's (2004) cointegration test shows cointegration between $\mathrm{CO} 2$ and Renew in OECD countries, but no cointegration between the two in non-OECD countries. The panel fully modified ordinary least squares results then indicate a negative effect of $\mathrm{CO} 2$ on Renew, and vice versa. However, $\mathrm{CO} 2$ and Renew do not affect each other in nonOECD countries. The panel VECM results support bidirec-

\footnotetext{
1 See https://datacatalog.worldbank.org/dataset/.

2 See https://www.iea.org/data-and-statistics.

3 To save space, we do not tabulate the results of the unit root test, but they are available upon request.
} 
Table 2. Pedroni’s (2004) Panel Cointegration Test Results

\begin{tabular}{l|c|c|c}
\hline Sample & FULL & OECD & non-OECD \\
\hline Dependent variable is & CO2 & CO2 & CO2 \\
\hline Panel variance & $3.570^{* * *}$ & $2.159^{* * *}$ & 0.272 \\
Panel $\rho$ & -0.434 & $-1.550^{* *}$ & 0.395 \\
Panel PP & $-1.696^{* *}$ & $-3.278^{* * *}$ & -0.267 \\
Panel ADF & $-1.600^{*}$ & $-3.338^{* * *}$ & -0.612 \\
Groupp & 0.920 & -0.793 & 1.301 \\
Group PP & -1.237 & $-3.438^{* * *}$ & 0.293 \\
Group ADF & -1.152 & $-3.259^{* * *}$ & -0.685 \\
\hline
\end{tabular}

This table shows the Pedroni (2004) panel cointegration test results. Statistics are asymptotically distributed as normal. The variance ratio test is right-sided, while the others are left-sided. ${ }^{* * * * * * *}$ and $*$ indicate statistical significance at the $1 \%, 5 \%$ and $10 \%$ levels, respectively.

Table 3. Panel Causality Test Results

\begin{tabular}{|c|c|c|c|c|c|}
\hline \multirow[t]{4}{*}{ Dependent variable } & \multicolumn{5}{|c|}{ Source of causation (CO2 vs. Renew) } \\
\hline & \multicolumn{2}{|c|}{ Short run } & & \multicolumn{2}{|l|}{ Long run } \\
\hline & \multicolumn{5}{|c|}{ Panel A: Full } \\
\hline & $\triangle \mathrm{CO} 2$ & $\Delta$ Renew & $\lambda$ & $\lambda / \triangle \mathrm{CO} 2$ & $\Lambda / \Delta$ Renew \\
\hline$\triangle \mathrm{CO} 2$ & -- & 0.58 & $4.72^{* *}$ & -- & $2.29^{*}$ \\
\hline \multirow[t]{3}{*}{$\Delta$ Renew } & 0.33 & -- & $149.97^{* * *}$ & $55.14^{* * *}$ & -- \\
\hline & \multicolumn{5}{|c|}{ Panel B: OECD } \\
\hline & $\triangle \mathrm{CO} 2$ & $\Delta$ Renew & $\lambda$ & $\lambda / \triangle \mathrm{CO} 2$ & N/ARenew \\
\hline$\triangle \mathrm{CO} 2$ & -- & $28.35^{* * *}$ & $3.20^{*}$ & -- & $19.75^{* * *}$ \\
\hline \multirow[t]{3}{*}{$\Delta$ Renew } & 0.91 & -- & $120.81^{* * *}$ & $49.14^{* * *}$ & -- \\
\hline & \multicolumn{5}{|c|}{ Panel C: non-OECD } \\
\hline & $\triangle \mathrm{CO} 2$ & $\Delta$ Renew & $\lambda$ & $\lambda / \triangle \mathrm{CO} 2$ & $N / \Delta$ Renew \\
\hline$\triangle \mathrm{CO} 2$ & -- & 1.18 & 2.50 & -- & 2.08 \\
\hline$\Delta$ Renew & 0.97 & -- & $79.62^{* * *}$ & $26.59^{* * *}$ & -- \\
\hline
\end{tabular}

This table shows the panel causality results. ${ }^{* * * * * *}$ and $*$ indicate statistical significance at the $1 \%, 5 \%$ and $10 \%$ levels, respectively. $\lambda$ are the error-correction items to examine the long-run relationship between $\mathrm{CO} 2$ and Renew, examining the lag terms of other variables help test for short-term causality.

tional causal links between CO2 and Renew among OECD countries and a unidirectional causal link from $\mathrm{CO} 2$ to $R e-$ new among non-OECD countries in the long run. 


\section{References}

Chang, C.-P., \& Hao, Y. (2017). Environmental performance, corruption and economic growth: Global evidence using a new data set. Applied Economics, 49(5), 498-514. https://doi.org/10.1080/00 036846.2016.1200186

Chen, X., Chen, Y. E., \& Chang, C.-P. (2019). The effects of environmental regulation and industrial structure on carbon dioxide emission: A non-linear investigation. Environmental Science and Pollution Research, 26(29), 30252-30267. https://doi.org/10.100 7/s11356-019-06150-6

Chen, X., Fu, Q., \& Chang, C.-P. (2021). What are the shocks of climate change on clean energy investment: A diversified exploration. Energy Economics, 95, 105136. https://doi.org/10.1016/j.enec o.2021.105136

Darnall, N., Jolley, G. J., \& Handfield, R. (2008). Environmental management systems and green supply chain management: Complements for sustainability? Business Strategy and the Environment, 17(1), 30-45. https://doi.org/10.1002/bse.557

Dubey, R., Gunasekaran, A., \& Ali, S. S. (2015). Exploring the relationship between leadership, operational practices, institutional pressures and environmental performance: A framework for green supply chain. International Journal of Production Economics, 160, 120-132. https://doi.org/10.1016/i.ijp e.2014.10.001

He, L., Liu, R., Zhong, Z., Wang, D., \& Xia, Y. (2019). Can green financial development promote renewable energy investment efficiency? A consideration of bank credit. Renewable Energy, 143, 974-984. http s://doi.org/10.1016/j.renene.2019.05.059
Hu, H., Wei, W., \& Chang, C.-P. (2020). The relationship between shale gas production and natural gas prices: An environmental investigation using structural breaks. Science of the Total Environment, 713, 136545. https://doi.org/10.1016/i.scitotenv.2020.136545

Narayan, P. K., \& Narayan, S. (2010). Carbon dioxide emissions and economic growth: Panel data evidence from developing countries. Energy Policy, 38(1), 661-666. https://doi.org/10.1016/i.enpol.2009.09.005

Pedroni, P. (2004). Panel cointegration: Asymptotic and finite sample properties of pooled time series tests with an application to the PPP hypothesis. Econometric Theory, 20(3), 597-625. https://doi.org/1 0.1017/s0266466604203073

Wang, K., Yan, M., Wang, Y., \& Chang, C.-P. (2020). The impact of environmental policy stringency on air quality. Atmospheric Environment, 231, 117522. http s://doi.org/10.1016/j.atmosenv.2020.117522

Wang, Yao, \& Zhi, Q. (2016). The role of green finance in environmental protection: Two aspects of market mechanism and policies. Energy Procedia, 104, 311-316. https://doi.org/10.1016/i.egypro.2016.12.05 $\underline{3}$

Wang, Yiwei, Wang, K., \& Wang, Q.-J. (2021). The comovement between epidemics and atmospheric quality in emerging countries. Emerging Markets Finance and Trade, 57(6), 1757-1772. https://doi.org/ 10.1080/1540496x.2021.1877133

Yang, Q. C., Feng, G. F., Chang, C. P., \& Wang, Q. J. (2021). Environmental protection and performance: A bi-directional assessment. Science of The Total Environment, 774, 145747. 